\title{
Reply: The Alleged (De)Politicization Problem of Post-Critical Pedagogy Reconsidered
}

\author{
Franz Kasper Krönig (TH Köln - University of Applied Sciences)
}

\begin{abstract}
:
This essay tries to intervene in the discussion between Naomi Hodgson on the one hand and Joris Vlieghe and Piotr Zamojski on the other about the meaning and function of the political in and for education. Firstly, it argues against the common charge of essentialism that is brought against ontological philosophies in general and the Heideggerian ontology of Vlieghe and Zamojski in particular. Secondly, the essay suggests the existentialist concept of 'the situation' as a theoretical nodal point that can grasp the inherently quasi-political dimension of pedagogical work and hence provide common ground for the two positions discussed.
\end{abstract}

Keywords:

essentialism; ontology; politicization; post-critical pedagogy; situational approach

Having co-authored the Manifesto for a Post-Critical Pedagogy (Hodgson et al., 2017) with Joris Vlieghe and Piotr Zamojski, Naomi Hodgson responds to subsequent theory developments regarding the relationship between education and politics (Vlieghe \& Zamojski, 2019; 2020). Hodgson's critique is twofold. First, she analyzes Vlieghe's and Zamojski's concept of politics as unnecessarily limited and inadequate. Second, she contends that their theoretical groundwork is (dangerously) essentialist. Whereas this paper suggests that the second point can be traced back to a misunderstanding of Vlieghe's and Zamojski's ontological framework, it argues that the role of 'the political' in pedagogical practice that Hodgson sees as too restricted by Vlieghe and Zamojski can be further elaborated and clarified by means of the existentialist concept of 'the situation.'

Concerning the concept of the political, Hodgson assumes that Vlieghe and Zamojski adhere to what she calls "politics in the sociological sense" (Hodgson, 2020, n.p.) in order to easily dismiss an inner relationship between education and politics. The other part of the "political difference" (Marchart, 2010) - namely the political as a nonformal, non-institutional, free-floating medium of the public rather than a separate political system - would be much harder to separate from the pedagogical, as Hodgson plausibly demonstrates. However, I propose that Vlieghe's and Zamojski's understanding of the political is beyond this binary. At the very least, these authors' as well as Arendt's separation of two spheres is not to be mistaken as a form of naïve realism or essentialism, with political 'things' and practices here and pedagogical ones there. When Vlieghe and Zamojski see "education as an autonomous sphere that has its own inherent logic, which is distinct from the private (economic) and political logic" (Vlieghe \& Zamojski, 2020, p. 871), the spatial metaphor of the sphere may create some misunderstandings. There is no sphere in the world that serves as a container that holds 'things' with political attributes in spatial separation from the pedagogical sphere. From Vlieghe's and Zamojski's theoretical stance, the political is rather a mode of being-in-the-world, a way of world-making (Goodman, 1978) that simultaneously 'makes' or forms meaning, selves, and interactions in a highly specific way. This ontology is clearly neither a form of realism nor essentialism. Being-in-the-world is explicitly not an ontic thing-like 'being' vis-à-vis an objective world that already exists, and vice versa. In non-Heideggerian terms and more concretely: For someone who observes politically (i.e., assumes the political being-in-the-world), everything is, of course, political. But in the very next moment, this person can switch to an aesthetic, pedagogical, religious, scientific, or everyday mode, as Ernst Cassirer (Cassirer, 1923) and Niklas Luhmann (Luhmann, 1995) have elaborated from a philosophical and a sociological perspective, respectively. Both are hardly essentialist thinkers. A natural disaster, for example, is either constructed as a sign from God, a consequence of political failure, an aesthetic spectacle, a cost factor, a juridical case, or a pedagogical situation that calls for pedagogical agency.

From this theoretical stance, the whole issue of the politicization of education becomes quite simple: I can construct the situation, my relationship with my students, the students themselves, my role, and my goals pedagogically (i.e., in accordance with pedagogical semantics) within a 
certain moment. And who would doubt that there are situations in which people immerse themselves in a radically or purely pedagogical mode (i.e., attitude, being-in-theworld)? They can also switch between modes and mostly have to, because there are organizational or economic issues to which they have to attend every day. They can also corrupt their pedagogical being-in-the-world by de-differentiating, by mixing it with other modes. Politicization refers to such corruption; economization, therapeutization, psychologization, aestheticization and sacralization serve as other examples. Given that these heteronomizations of the pedagogical are ubiquitous, it is more than reasonable to defend an autonomy of the pedagogical, I would say.

But one thing is puzzling here: Why is it so much more difficult and controversial to describe the "logic of education" (Vlieghe \& Zamojski, 2020, p. 869) than the logics of science, religion, the economy, or art? At the very least there are established discussions with regard to the respective values (Rickert, 1912; Steinvorth, 1978; Weber, 1922) the operational modes, the functions, and the interactional roles in these spheres or systems (Luhmann, 1995). Whatever one may think of Vlieghe's and Zamojski's proposal for a definition of the educational logic as "unconditional affirmation of the present" (Vlieghe \& Zamojski, 2020, p. 869), it proves their point that the established educational discipline must obviously suffer such proposals due to its paradigmatic weakness (Evans et al., 2016; Kuhn, 2012), i.e., its inability to refer to established educational concepts and criteria that make pedagogical practice differentiable from other forms of practice. Indeed, it demonstrates that the pedagogical is a precarious sphere or being-in-the-world in need of self-affirmation and theoretical support against all forms of heteronomization processes, of which politicization is just one example. However, we can imagine a purely economical being-in-the-world (Bellmann, 1999), and the Enlightenment idea of a purely scientific and a purely aesthetic attitude to the world and to oneself has been thoroughly described (Kant, 1914; 1781/1998). Although all these notions of purity are hardly compatible with current social science discourses, they still convey some orientating meaning for these spheres' self-descriptions. Before considering its relationship with politics - according to the argument - education needs a concept of the pedagogical, which is nothing but a (non-essentialist) description of the pedagogical being-in-the-world with emphasis on its potential autonomy.

At the same time, this pedagogical autonomy should not be taken to de-problematize, mollify, or harmonize pedagogical situations. Problems that seem to be unambiguously political from a political stance (being-inthe-world) are not blinded out by the pedagogical gaze, but rather are constructed pedagogically. That pedagogy can deal with real-world problems on its own terms (i.e., without politicizing itself) has been demonstrated by the 'situational approach' in the 1970s (Zimmer, 1976). Problems like "environmental disasters including wildfires and floods, the killing of black citizens by police in the US, and a pandemic" (Hodgson, 2020, n.p.) that Hodgson claims to render pedagogy "unavoidably political" today (Hodgson, 2020, n.p.), could be starting points for pedagogical practice in the situational approach. The fact, however, that political or scientific observers say so is not sufficient, because a situation must always be both experienceable and to some extent modifiable for children. The concept of the situation that theorizes agency in a problematic world from a purely pedagogical stance was developed by Jean-Paul Sartre (Sartre, 1966), introduced to pedagogy by Paolo Freire (Freire, 1970/2005), and broadly established in the critical didactics of the 1970s in Germany (Zimmer, 1976). I want to argue that this concept of 'the situation' upholds a radical autonomy of pedagogy and facilitates pedagogical practice addressing problems that might be labeled as political from a political or activist perspective.

For Vlieghe and Zamojski, pedagogy is not a sphere outside of the world and the argument for pedagogical autonomy is not a defense against the invasion of societal problems. Ideas like these only make sense for educational philosophies that believe in 'the natural' (Rousseau) or 'the sacred' (Fröbel) in children, which best unfold detached from the corrupting influence of the (neither natural nor sacred) society. The underlying bifurcation of the I and the world is exactly what Vlieghe and Zamojski overcome with the Heideggerian concept of being-in-the-world. For Sartre, this being-in-the-world is always concrete in the sense that subjective freedom is confronted with various forms of facticity, i.e., constraints, conditions, adversities, and contingent givens. The time and place I was born, the language I grew up with, the choices I have made, and the materiality of my body are examples of contingent givens with which I have to deal. However, these facticities do not determine how I deal with them, hence I am free, in Sartre's view. This existentialist concept of the situation points out that freedom always deals with facticity, which means that pedagogical practice is always 'situated' and thus concerned with constraints to freedom; nota bene, not in the abstract, not on a sociological level, not from an outside perspective, but from the immanent standpoint of the pedagogical situation, that is, from the life-world experiences of the children or students and pedagogues. Injustice, for example, is a common problem in pedagogical situations. However, a pedagogical approach refrains from applying a ready-made political concept of injustice to a concrete situation. To the contrary, being-in-the-world pedagogically means being interested in the actual individual perceptions, attitudes, interests, and ideas of the children in the light of their potential development, and to be interested in ways to responsibly influence such developments without inhibiting their freedom and denying the constitutive paradoxes of these attempts. This does not mean to banalize and individualize injustice. Teaching children to cope with or adapt to injustice on an individual basis by invisibilizing the societal structures 
of injustice is clearly not the post-critical approach. Postcritical pedagogy aims for change. But the pedagogical version of change "should be called transformation rather than emancipation" (Vlieghe \& Zamojski, 2020, p. 870), in order to fend off pre-defined political conceptions of the world with drawn battle lines that render children mere extras in the political dramas we have already decided to stage, as Arendt criticizes (Arendt, 1961). When Vlieghe and Zamojski end on a conciliatory note by pointing out the political function of a non-politicized pedagogy, they temporalize an alleged paradox: "one must first experience pure potentiality in the autonomous, separate sphere of education, to be able to intervene in the current order of things in politics" (Vlieghe \& Zamojski, 2020, p. 874). The existentialist concept of the situation demonstrates that there is not even a paradox to begin with. From a pedagogical standpoint, transformations in concrete situations that deal with freedom and facticity are neither political nor preconditions for future political practice, but already an immanent pedagogical counterpart to the political. Although post-critical pedagogy is no fight against anything, it is an engagement of and for freedom under the condition of realworld facticities.

\section{References}

Arendt, H. (1961). The crisis in education. In H. Arendt (Ed.), Between past and future: Eight exercises in political thought (pp. 173-196). Viking Press.

Bellmann, J. (1999). Die Konstruktion des Ökonomischen bei Eduard Spranger und Theodor Litt. Zeitschrift für Pädagogik, 45(2), 261-279.

Cassirer, E. (1923). Philosophie der symbolischen Formen. Erster Teil: Die Sprache. Bruno Cassirer.

Evans, E. D., Gomez, C. J., \& McFarland, D. A. (2016). Measuring paradigmaticness of disciplines using text. Sociological Science, 3, 757-778. https://doi.org/10.15195/v3.a32

Freire, Paolo (2005). Pedagogy of the oppressed. (M. Bergman Ramos, Trans.). continuum. (Original work published 1970)

Goodman, N. (1978). Ways of worldmaking. Hackett.

Hodgson, N. (2020). Post-critique, politics, and the political in educational philosophy. On Education. Journal for Research and Debate, 3(9), n.p. https://doi.org/10.17899/on_ed.2020.9.3

Hodgson, N., Vlieghe, J., \& Zamojski, P. (2017). Manifesto for a post-critical pedagogy. punctum books.

Kant, I. (1914). Kant's critique of judgement. (2nd ed.) (J. H. Bernard, Trans.). Macmillan.

Kant, I. (1998). Critique of pure reason. Cambridge University Press. (Original work published 1781)

Kuhn, T. S. (2012). The structure of scientific revolutions. (50th anniversary ed.). The University of Chicago Press.

Luhmann, N. (1995). Social systems. Stanford University Press.

Marchart, O. (2010). Die politische Differenz. Suhrkamp.

Rickert, H. (1912). Lebenswerte und Kulturwerte. Logos, 12(2), 131-166.

Sartre, J.-P. (1966). Being and nothingness. A phenomenological essay on ontology. Pocket Books.

Steinvorth, U. (1978). Wertfreiheit der Wissenschaften bei Marx, Weber und Adorno. Zeitschrift für allgemeine Wissenschaftstheorie, 9(2), 293-306.

Vlieghe, J., \& Zamojski, P. (2019). Towards an ontology of teaching. Thing-centred pedagogy, affirmation and love for the world. Springer Nature.

Vlieghe, J., \& Zamojski, P. (2020). Redefining education and politics: On the paradoxical relation between two separate spheres. Policy Futures in Education, 18(7), 864-877. https://doi.org/10.1177/1478210320943808

Weber, M. (1922). Grundriß der Sozialökonomik. III. Abteilung. Wirtschaft und Gesellschaft. J. C. B. Mohr (Paul Siebeck).

Zimmer, J. (1976). Ein Bezugsrahmen vorschulischer Curriculumsentwicklung, In J. Zimmer (Ed.), Curriculumentwicklung im Vorschulbereich. (Vol. 1, 2nd ed.) (pp. 9-60). Piper. 


\section{Recommended Citation}

Krönig, F. K. (2020). The alleged (de)politicization problem of post-critical pedagogy reconsidered. On Education. Journal for Research and Debate, 3(9). https://doi.org/10.17899/on_ed.2020.9.14

\section{About the Author}

Franz Kasper Krönig is professor of cultural pedagogy and didactics at the Cologne University of Applied Sciences (TH Köln). His research interests range from 'big questions' of the philosophy of education, the philosophy of science, and sociological theories of societal transformations to more practice-related questions concerning inclusive pedagogy and cultural education. 